\title{
CARMEN REINHART AND KENNETH ROGOFF IN A TIME OF FISCAL AUSTERITY: A CRITICAL ANALYSIS OF THE EXPANSIONARY AUSTERITY THEORY
}

\author{
ALBERTO BOTTA (*) \\ Nota presentata dal m.e. Silvio Beretta \\ (Adunanza del 23 maggio 2013)
}

SuNTO. - In quest'articolo si propone un'analisi critica della teoria dell'austerità espansiva. In primo luogo, si analizza il ben noto e assai dibattuto articolo di Carmen Reinhart e Kenneth Rogoff circa la possibile correlazione negative tra crescita economica e debito pubblico che potrebbe emerge in presenza di uno stock di debito pubblico superiore al 90 percento del PIL. Si analizzano quindi i contributi empirici che più direttamente sostengono i possibili effetti espansivi di politiche di consolidamento fiscale. Nella parte finale dell'articolo, si propone un semplice modello teorico di breve periodo attraverso il quale si mostrano le circostanze economiche assai estreme, specifiche e tutt'altro che scontate in virtù delle quali l'austerità espansiva potrebbe aver luogo. La teoria dell'austerità espansiva appare difficilmente applicabile a economie sovrane dal punto di vista monetario, ovvero in presenza di politiche monetarie accomodanti, ovvero in sistemi economici chiusi e poco integrati sui mercati internazionali dei beni.

$$
* * *
$$

ABSTRACT. - In this paper, we provide a critical analysis of the theory of the expansionary austerity. We take the hotly debated contribution by Carmen Reinhart and Kenneth Rogoff on the supposedly negative relationship between public debt and economic growth (when the debt-to-GDP ratio overcomes the 90 percent threshold) as the starting point of our analysis. We then move to analyze those contributions that more directly point to the possible expansionary outcomes of tough fiscal retrenchments. We

(*) Department of Law and Economics, Mediterranean University of Reggio Calabria, via dei Bianchi 2, 89127 Reggio Calabria, Italy.

E-mail: abotta@eco.unipv.it 
eventually criticize the main conclusions of the expansionary austerity theory by presenting a simple short-run theoretical model. We show that fiscal consolidation might have expansionary outcomes only under pretty extreme, or very specific and uncertain circumstances. Expansionary austerity would hardly take place in the context of monetarily sovereign economies, or in presence of an accommodative monetary policy like that implemented by the ECB since late 2011, or into economic systems that are poorly integrated on international goods markets.

\section{INTRODUCTION}

In 2010, Carmen Reinhart and Kenneth Rogoff published a hotly debated and influential paper, "Growth in a time of debt". This work was a sort of follow-up of some previous contributions in which the two authors, together with Michael Savastano, developed the "debt intolerance" theory. According to the authors, the history of several developing and emerging countries clearly shows that the accumulation of public and private debt, in particular foreign debt, recurrently represented a source of economic instability, economic stagnation and recession. This holds even at debt levels that would otherwise have been considered as easily manageable in developed economies. Such a negative and easy-to-emerge effect of developing countries' (foreign) debt on their own macroeconomic performances is the result of the reluctance of (international) financial operators to accept even low levels of indebtedness in countries recording a long tradition of complicated debt management and serial defaults.

In their 2010 article, Reinhart and Rogoff somehow extended the theory of the debt intolerance to the case of developed countries. More in detail, they asserted that a statistical negative correlation exists between economic growth and public debt when public debt stocks reach levels higher than 90 percent of GDP. Accordingly, public debt stocks can represent a significant problem developed countries' policymakers have to carefully and suddenly deal with in presence of debt-toGDP ratios approaching the above threshold if they want to maintain and boost economic growth.

Reinhart and Rogoff did not directly and explicitly pointed out quick fiscal correction as the best strategy to tackle with the problem of increasing public debt stocks in both the US and in European countries. Nevertheless, two years after the outbreak of the worldwide finan- 
cial crisis and "Great Recession", and the ensuing massive intervention by most governments worldwide to bail out close-to-bankruptcy financial systems and avoid even deeper contractions, their empirical analysis was largely perceived as the definitive proof of the validity of the theory of "the expansionary fiscal austerity", and of the need for a sudden return to fiscal consolidation. According to the former House Budget Committee Chairman Paul Ryan, for instance, "economists who have studied sovereign debt tell us that letting total debt rise above 90 percent of GDP creates a drag on economic growth and intensifies the risk of a debt-fueled economic crisis". Analogously, Olli Rehn, the Finnish European Commissioner to EU economic and financial affairs, has recently stated that "it is widely acknowledged [...] that when public debt levels rise about $90 \%$ they tend to have a negative economic dynamism, which translates into low growth for many years. That is why consistent and carefully calibrated fiscal consolidation remains necessary in Europe".

The long-lasting nature of some economic problems (read a 5year long recession in Greece and a permanently high level of unemployment - in particular youth unemployment - in Spain and Italy) in most peripheral countries of the Eurozone, as well as pale economic performances if not signs of stagnation and slight recession in some central economies like Netherlands, Finland and even Germany, above all when compared to the much more brilliant economic dynamics recorded in the US, have now sparked a heated debate on the solidity of the "expansionary austerity" hypothesis, and of the empirical analyses which underpin it, directly or indirectly.

The aim of this paper is to provide a simple but comprehensive overview of the two conflicting hypotheses, i.e. the idea that welldesigned fiscal consolidations may be conducive to growth even in the short run and even when implemented in a downswing, and the opposite traditional Keynesian-type rejection of restrictive fiscal measures in times of economic contraction. In particular, we first provide a brief analysis of the arguments put forward by the supporters of the expansionary austerity, and of the economic mechanisms through which expansionary fiscal consolidations might actually materialize. We then present the critiques to the abovementioned contribution by Carmen Reinhart and Kenneth Rogoff, as well as the critical responses to the (prevalently) empirical works that more directly support the logic of the expansionary austerity. We conclude by presenting a sim- 
ple short-run model through which we try to enlighten the specific economic conditions and assumptions that could make expansionary fiscal consolidation possible. In this regard, we stress that the economic mechanisms at the basis of the expansionary austerity hypothesis are far from being automatic. Actually, they fundamentally depend on two core aspects, at the very least: first, the uncertain change in economic agents expectations, both consumers and entrepreneurs, in presence of tough and likely long-lasting fiscal corrections; second, the dynamics of interest rates on financial markets, as strongly influenced by the behavior of the domestic Central Bank and the way it conducts domestic monetary policy. Our conclusion is that the theoretical fundamentals of the expansionary austerity hypothesis are fragile and state- or institution-contingent. Therefore, they must be carefully re-considered and contextualized before using such theoretical apparatus as a general and universal guide for conducting fiscal policy.

\section{REINHART AND ROGOFF'S DEBT THRESHOLD, THE THEORY OF "EXPANSIONARY AUSTERITY", AND ITS CRITIQUES}

If one wants to understand why austerity policies in the Eurozone, and the theories that back them (more or less explicitly), represent such an important topic in economics, we think that a brief look at macroeconomic forecasts periodically provided by the IMF represents a good starting point. In Tab. 1 below, we show IMF's forecasts as released twice a year (in April and October) through the well-known IMF World Economic Outlook.

We focus on registered and expected GDP growth rates, as well as on the dynamics of debt-to-GDP ratios, from 2007 (i.e. the first year in which the signs of the worldwide financial crisis started to emerge) to 2016. We consider a bunch of central European countries like Germany, Finland and Netherlands, i.e. apparently the most convinced supporters of the austerity doctrine; the so-called Eurozone PIIGS, i.e. Portugal, Ireland, Italy, Greece and Spain; finally, the US economy. We compare the statistics presented by the IMF in October 2011 with respect to their updates released in October 2013. We choose to compare each other IMF statistics elaborated since October 2011 on in order to grasp the effects that bailed-out/structural 
reforms packages in some peripheral Eurozone countries ${ }^{1}$ could be expected to have on their future economic performances. In Tab. 1, we show in grey cells IMF growth rates forecasts that have been revised downward, as well as IMF "public finance" previsions that have been updated upward in light of higher than expected debt-toGDP ratios.

From the data above, it emerges clearly that, for most of the Eurozone countries reported in Tab. 1, in 2011 the IMF significantly overstated the expected future growth rates and, at the same time, expected a much faster consolidation of Eurozone countries' public finances (read stable or decreasing debt-to-GDP ratios). This applies to both peripheral countries and supposedly virtuous central economies (with the only exception of Germany). Indeed, in both cases, by the end of 2013, the IMF had significantly reduced recorded and expected growth rates with respect to 2011. Symmetrically, it had increased its estimations about realized or expected debt-to-GDP ratios². If the initial 2011 IMF statistics were thought to account for the prospected positive economic effects of Eurozone austerity, it seems evident that these estimates were badly wrong, and Eurozone austerity did not deliver the expected results. Interestingly enough, and perhaps paradoxically, economic recovery and public finance consolidation have been much more pronounced in the USA, even though the US government did not com-

1 Together with the European Central Bank and the European Commission, the IMF is a member of the so-called Troika. Since 2010, the Troika discusses with national European governments those economic reforms, usually restrictive fiscal measures and structural reforms on the labor and good markets (read labor market flexibilization and public firms' privatization) that must be enacted domestically in order to benefit of external financial support, and that are expected (at least by the abovementioned institutions) to restore economic solidity. In this regard, the Greek government and Troika agreed upon a First Economic Adjustment Program for Greece in May 2010. Ireland and Portugal signed together with Troika bail-out/structural reform packages on November 2010 and April/May 2011, respectively.

2 In the case of Greece, we put downward corrections in the IMF estimations of the domestic debt-to-GDP ratio in dark grey cells in Tab. 1. These records, that could seem highly surprising at first sight, are the effects of Greece 2012 partial default on its total debt burden. Such a revision is not to be intended as the result of a genuine process of economic stabilization. Rather, it is the worrisome outcome of Greece never-ending economic collapse. 


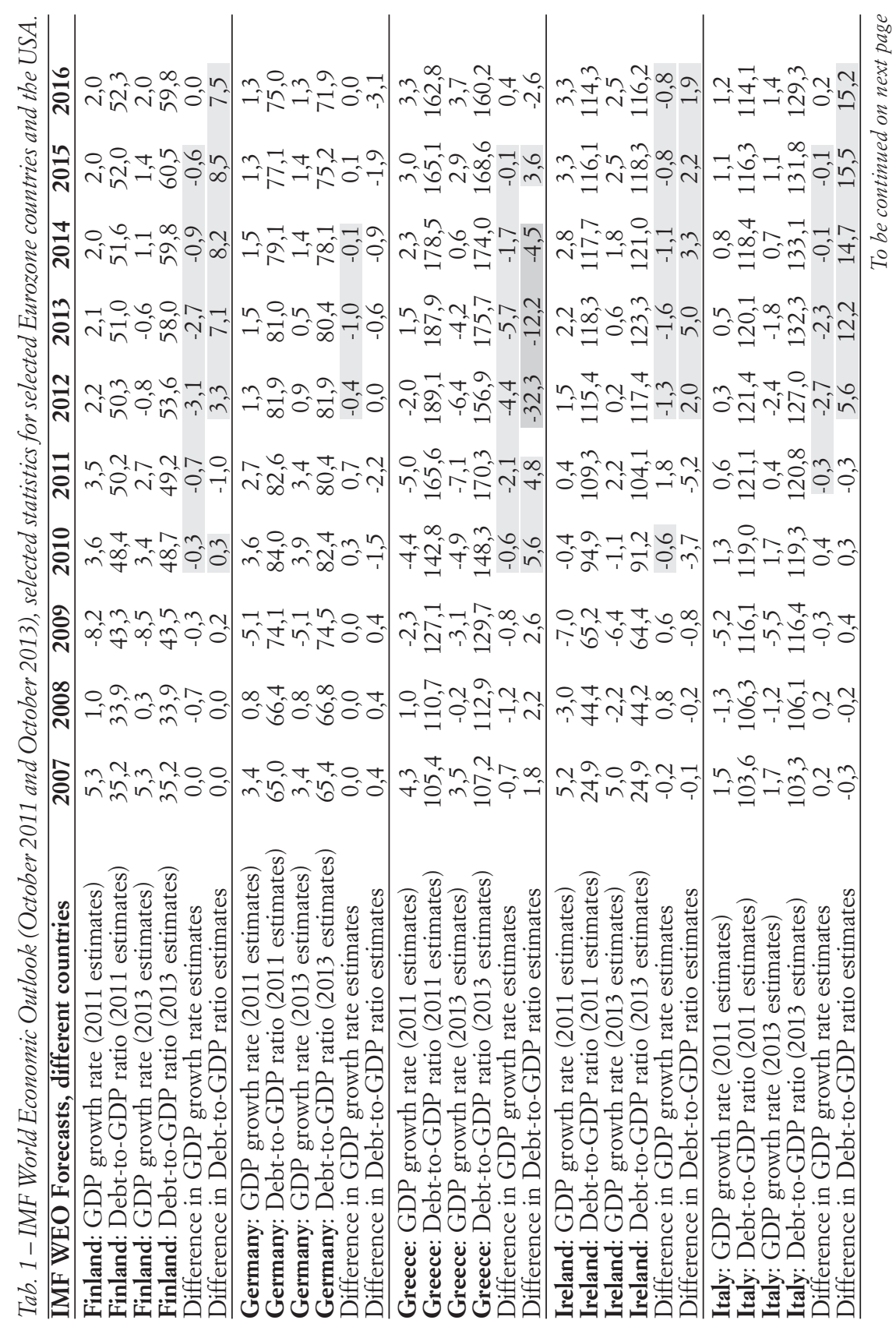




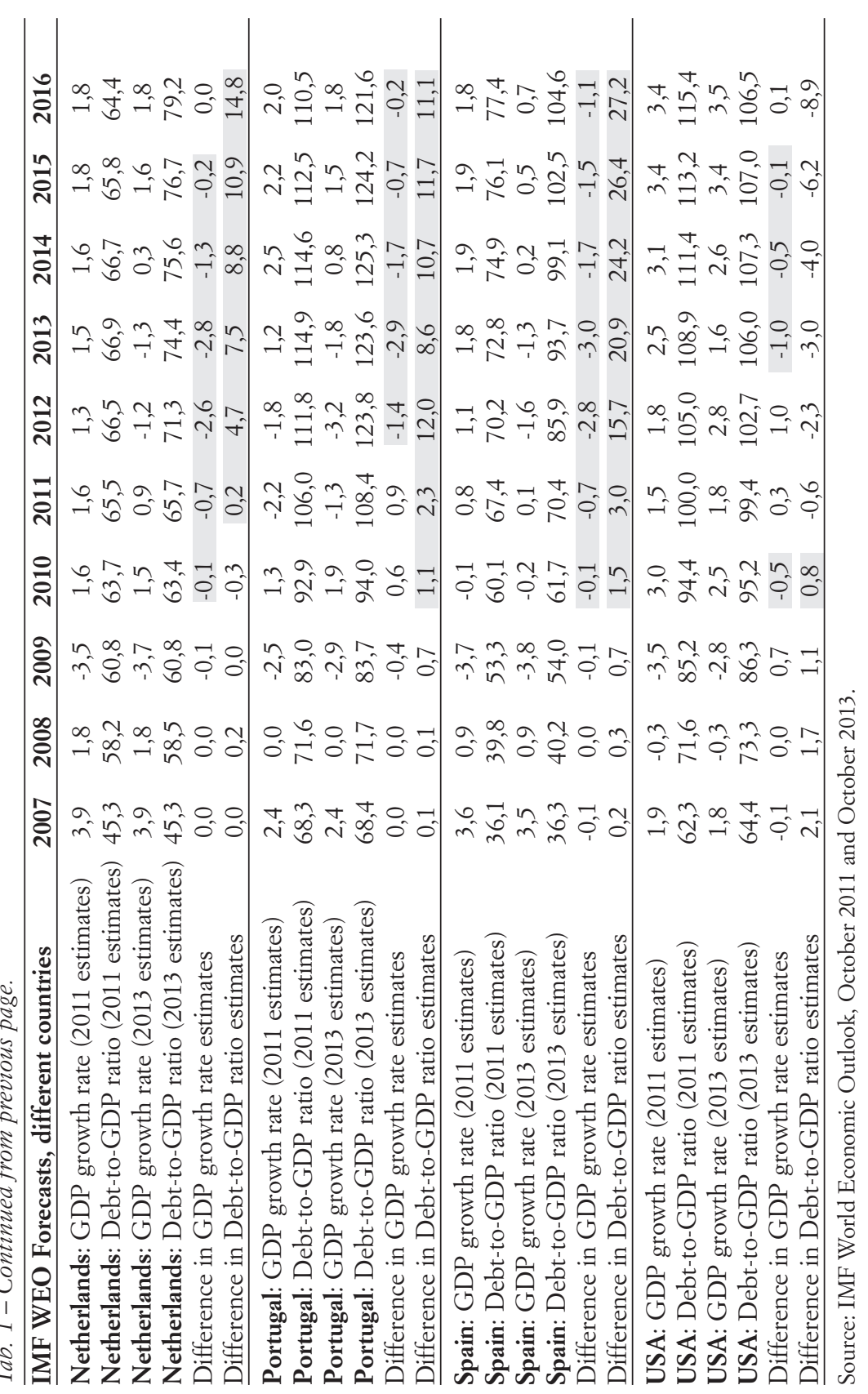


ply to most of the prescriptions of the austerity doctrine, and has maintained a much more expansionary fiscal policy stance ${ }^{3}$.

In light of these data, it is necessary to investigate why austerity measures did not pay off and what went wrong with the economic analyses sponsoring them. We will try to answer such questions by presenting a very simple model in Section 3 of this paper. Before this, however, it would be helpful to briefly review the existing literature on the so-called expansionary austerity, which represents the theoretical framework of the austerity measures implemented in the Eurozone.

The theory of the "expansionary fiscal austerity" firstly emerged with the idea that, at least under certain conditions, discretionary expansionary fiscal policies may have non-Keynesian effects, so that they may prove to be ineffective to stimulate economic activity and, at the same time, they may put at risk the solidity of public finances and of the whole financial system of the economy (see Giavazzi and Pagano, 1990 and 1996; Alesina and Perotti, 1995; Alesina and Ardagna, 2010 and 2012) ${ }^{4}$. Symmetrically, well-conceived fiscal restrictions are expected to stimulate both private consumption and investment expenditures, so that the overall economic activity will eventually expand rather than

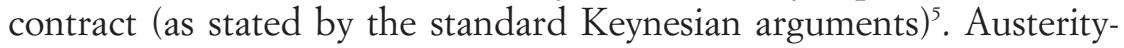
led expansion might be even stronger if austerity measures favor wage

3 According to the data reported in Tab. 1, at the end of 2013 the IMF revised downward its estimations as to real GDP growth in the US in 2013, 2014 and 2015. This downward revision notwithstanding, one has to remind that realized/expected average growth in the US from 2010 on still remains two to four times higher than that projected in the selected Eurozone countries. The US rejections of premature fiscal consolidation seems thus to have positively contributed to spur economic growth at levels that are simply unthinkable in Europe since 2008, and eventually to keep the debt-to-GDP ratio under control. In the end, it appears absolutely reasonable to wonder if fiscal stimuli supporting fast growth rather than contractionary fiscal restrictions constitute the most promising strategy to stabilize fiscal variables themselves.

4 See Sutherland (1997) for the case of possible non-Keynesian effects of expansionary fiscal measures when undertaken in a context of bigh public debt. Perotti (2012) also stresses that fiscal contractions may indeed be expansionary in presence of bigh interest rates, in particular when they contribute to reduce risk premia on financial assets, on government bonds first of all, and prompt a considerable reduction in nominal interest rates.

5 The theory of expansionary austerity obviously takes part to the much older debate on the effectiveness of fiscal policy that dates back to the $60 \mathrm{~s}$ and to the theorization of the crowding-out effects of expansionary fiscal policies on private investments 
moderation and the occurrence of a sort of internal devaluation that boosts the international competitiveness of home-made goods and hence exports.

According to the supporters of the expansionary austerity, welldesigned fiscal consolidation must take the form of deep, persistent and credible cuts in public expenditures, in particular public transfers, perhaps followed by reductions in the tax burden on the households. In their view, such a shift in fiscal policy may constitute a sign of "regime change" to the eyes of economic agents, leading them to increase consumptions and unleash investment programs. Cuts in public wages, public employment, and/or unemployment benefits can also lead to wage moderation, real exchange rate devaluation and, eventually, increasing exports.

The most recent critiques to the theory of expansionary austerity mainly address the weaknesses of the empirical analyses through which they try to validate their non-Keynesian view of fiscal policy outcomes. As to the abovementioned article by Carmen Reinhart and Kenneth Rogoff (which, let's repeat it for the sake of clarity, does not explicitly or directly point out expansionary austerity as the main way out of the ongoing sovereign debt crisis), harsh criticisms emerged after Herndon et al. (2013) demonstrated that the empirical analysis presented in that paper was badly flawed by some technical errors and by a debatable procedure for selecting and weighting cross-country data. As to the first problem, Reinhart and Rogoff made simple spreadsheet errors and did not include data from Austria, Australia, Belgium, Canada and Denmark in the computation of the statistics at the center of their study. Such mistake does influence the conclusion reached by their work. Taking into consideration Belgium (i.e. a country scoring a remarkably long history of high public debt stock with nevertheless positive average growth records), for instance, would have increased the average growth rate associated to developed economies experiencing episodes of high debt-to-GDP ratios (higher than the 90 percent threshold level) in the aftermath of the Second World War. As to the

in the traditional IS/LM model. It may also be conceived as an evolution of the wellknown Ricardian equivalence hypothesis, i.e. the idea that debt-financed fiscal policies are ineffective if economic agents anticipate future increases in taxation, and therefore immediately cut consumption and investment expenditures. 
selection process, the authors did voluntarily neglect to consider the positive average growth rates registered in Australia, Canada, and New Zealand from 1946 and 1950 even in presence of high public debt stocks. In the case of New Zealand, only data from 1951 are considered, in which this country plummeted in a bad recession with GDP contraction amounting to $7,6 \%$. Such a choice appears even more incomprehensible since that exactly the opposite logic was adopted in the case of the US.

Even further, in their study Reinhart and Rogoff first re-group country-year growth data into different sub-samples according to the corresponding public debt-to-GDP ratio. Four public debt-to-GDP categories are assumed: below than 30 percent; between 30 and 60 percent; between 60 and 90 percent; higher than 90 percent. Into each sub-group, mean growth rates at country level are averaged out in order to compute the average cross-country growth rate associated to each specific debt category. Through such an averaging strategy, the authors assign equal weights to each country into each specific debt-to-GDP sub-sample without paying attention to the length of the timespan during which an economy falls into a given specific debt-to-GDP category. In the case of the "above 90 percent" category, the negative growth performance observed in New Zealand in only one year, i.e. in 1951, has the same relevance than the average positive growth rates registered in Greece and the UK over 19 years. Had Reinhart and Rogoff adopted the alternative weighing and averaging strategy proposed by Herndon et al. (2013), the average growth rate associated to the "above 90 percent" debt category would have been equal to 2 percent rather than -0.1 percent.

Other analyses more directly embrace and put forward the expansionary austerity standpoint. Most authors build up their empirical tests on the concept of cyclically adjusted primary public balance ${ }^{6}$ (henceforth CAPB), and take significant shifts ${ }^{7}$ in countries' CAPBs as signs of discretionary expansionary or restrictive fiscal policies. The authors then use the identified episodes of fiscal adjustments to econometrically

6 The cyclically adjusted primary public balance (CAPB) is the difference between government expenditures and government revenues (net of interest payments) that would prevail should the economy work at full potential. Remarkable changes in a country CAPB are considered as genuine signs of discretionary fiscal measures since that they are "polished" from the effects that economic cycles, through the functioning of automatic stabilizers, would naturally entail on actual primary public balances. 
explain cross-country growth performances and public debt dynamics in the years following the launch of corrective fiscal packages.

Criticisms to such a methodology are mostly based on the fact that the adopted measures of cyclically adjusted primary balances are not capable to completely remove the effects of the economic cycle on the evolution of public finances, no matter how carefully the cyclically adjusted primary balance itself is defined and computed. For instance, during phases of economic expansions the prices of financial assets usually tend to increase, this way improving primary public balances by raising tax revenues. However, such an effect of economic cycle on public finances is not detected by the abovementioned CAPB-centered methodology. Eventually, a pure cyclical component of public balance dynamics, which is positively correlated with the economic cycle, is misinterpreted and wrongly accounted for a discretionary fiscal policy shock. The positive correlation between apparent fiscal consolidation and economic expansion is easy to emerge, but it is the outcome of a biased empirical approach and the econometric misunderstanding of rather different economic mechanisms.

On top of the abovementioned problem of precisely computing the CAPB, a perhaps more relevant causality issue does emerge. Very likely, fiscal variables and economic growth feedback on each other and both emerge as endogenous variables. The causality runs both ways: fiscal policy can surely influence economic performances, positively or negatively. Economic dynamics, in turn, also has clear implications in terms of improving or worsening public balances, as well as on the type of fiscal stances governmental authorities follows. The results of the

7 Alesina and Perotti (1995), for instance, interpret improvements (deteriorations) in a country's CAPB in the order of at least 1,5 percentage points over GDP as examples of "very tight" ("very loose") discretionary fiscal policies. This is also the definition of fiscal adjustment followed by Alesina and Ardagna (2010). Alesina and Ardagna (2012), on the contrary, adopt a more complex definition of fiscal adjustment, according to which "a fiscal adjustment is either 1) a two year period in which the cyclically adjusted primary balance/GDP improves in each year and the cumulative improvement is at least two points of the balance/GDP ratio; a three year or more period in which the cyclically adjusted primary balance over GDP improves in each year and the cumulative improvement is eat least three points of the Balance/GDP ratio (Alesina and Ardagna, 2012, pp. 5-6)".

8 Policy makers, for instance, may adopt a restrictive fiscal policy stance as a response to, and in order to tame, excessive economic expansions putting at risk price 
CAPB-based literature may thus be misleading simply because they take changes in the cyclically adjusted primary balance as the exogenous explicative variable of economic dynamics, whist it is the endogenous one.

In order to address such an estimation problem, Guajardo et al. (2011) suggest an alternative method to identify episodes of fiscal adjustments. This approach is based on the direct analysis of fiscal authorities' historical documents and decisions. What eventually emerges from the adoption of this alternative methodology is that "a 1 percent of GDP fiscal consolidation reduces real private consumption by 0.75 percent within two years, while real GDP declines by 0.62 percent $[\ldots]$ Our main finding that fiscal consolidation is contractionary holds up in cases where one would most expect fiscal consolidation to raise private domestic demand. In particular, even large spendingbased fiscal retrenchments are contractionary, as are fiscal consolidations occurring in economies with a high perceived sovereign default risk (Guajardo et al., 2011, p. 29)".

Most of the contributions discussed so far test the empirical validity of the expansionary austerity hypothesis. However, they do not address to the in-deep theoretical consistency and coherence of such a theory. In the following section of this work we aim at enlightening the theoretical or, say, logical fragility of the expansionary austerity doctrine. In particular, we want to stress that the expansionary effects of fiscal austerity are by no means automatic, but rather depend on a series of contingent factors, as well as on peculiar or country-specific institutional arrangements. Accordingly, the expansionary austerity is not to perceive as a well-established natural rule on the base on which policy makers should inform the design of fiscal policies.

\section{A SIMPLE SHORT-RUN MODEL ON THE EXPANSIONARY/ CONTRACTIONARY EFFECTS OF FISCAL ADJUSTMENTS}

Our simple model is a sort of open-economy version of a previous model presented by Palley (2010). Even further, whilst in Palley (2010)

stability and overheating the economy. Here fiscal policy adjustments are a consequence rather than the determinants of economic growth. 
the in-built result of his theoretical exercise is that austerity measures inevitably lead to economic contraction, here we adopt a broader perspective and a more general framework in order to allow for the possible expansionary effects of fiscal retrenchments?.

In line with the literature on the expansionary austerity, we focus on the short-run dynamics of such an economy, in particular on the effects of restrictive fiscal adjustments on economic activity and on public balance deficit. In this regard, we assume that the economy does not work at its full potential in order to allow for possible (fiscal) policy-driven expansions of aggregate demand and, hence, current production. Indeed, the expansionary austerity literature argues that well-designed fiscal adjustments may boost economic activity through both a demand channel, i.e. by stimulating private consumption, investment expenditures, and export dynamics, and a supply channel, i.e. by affecting the total supply of labor. In this paper, we focus only on the operativeness of the first channel, since that the supply channel will reasonably show its effects in a medium/long-run time horizon only ${ }^{10}$.

Due to the short-run perspective of our analysis, we assume all stock variables, i.e. the home economy capital stock $K$, public debt $D$, and the total amount of (past and present) private sector's borrowing from banks $C R$, as given. Into this framework, equations (1) - (8) describe the production/supply side on the economy; equations (9) (14) describe the demand side; equations (15) - (17), finally, formalize the public budget and the financial side of our economy, i.e. how the interest rates are determined and how they change.

9 In our view, differently from Palley (2010), it makes no sense to criticize the effectiveness of fiscal austerity (and the solidity of the expansionary austerity hypothesis) through a theoretical model that assumes, a priori, contractionary fiscal consolidations. Rather, we think that a more effective critique of expansionary austerity should point out the specific perhaps extreme conditions under which it could materialize. This is what we try to show in the present paper.

10 Alesina and Ardagna (2010), for instance, argue that lower public sector employment, lower public sector wages, and (or) lower degrees of labor market protection (say cut in unemployment benefits), tend to increase individual labor supply and reduce trade unions' bargaining power. It is easy to see how these effects of fiscal adjustments may stimulate growth in supply-side mainstream models. 
The production/supply side block:
(1) $Y=\alpha N$
(2) $Y^{*}=\alpha L$
(3) $\frac{Y}{K}=\frac{Y}{Y^{*}} \frac{Y^{*}}{K}=\chi \beta$
(4) $U=L-N$ or (4.b) $u=\frac{L-N}{L}=1-\frac{Y}{\alpha L}=1-\chi$

(5) $w=p^{e} l\left(\alpha, u_{-1}, z\left(b_{u}\right)\right)$

(6) $p_{H}=(1+m) \frac{w}{\alpha}$

(7) $q=\frac{e p^{F}}{p_{H}}=\frac{e p^{F} \alpha}{(1+m) p^{e} l\left(\alpha, u_{-1}, z\left(b_{u}\right)\right)}$

(8) $P Y=W+\Pi=w N+\Pi$

The demand side block:

(9) $Y=C+I+G+N X$

(10) $C=\left(1-s_{w}\right)\left(1-t_{w}\right)\left[w N+\operatorname{Tr}^{G}+b_{u} U\right]+\left(1-s_{\pi}\right)\left(1-t_{\pi}\right)\left[\Pi-i_{c r} C R\right]$ or:

(10.b) $\frac{C}{K}=\left(1-s_{w}\right)\left(1-t_{w}\right)\left[\chi \frac{\beta}{\alpha}\left(w-b_{u}\right)+b_{u} \frac{\beta}{\alpha}+\rho\right]+\left(1-s_{\pi}\right)\left(1-t_{\pi}\right)\left[r-i_{c r} \lambda\right]$

(11) $\frac{I}{K}=\sigma+a \chi+v r-h i_{c r}$

(12) $\frac{G}{K}=\gamma$

(13) $\frac{N X}{K}=\epsilon_{q} q-\epsilon_{\chi} \chi$

(14) $s_{w}=f\left(t_{w}^{e}, \operatorname{Tr}^{G}\right)$ with $\left(\partial s_{w} / \partial t_{w}^{e}\right)>0 ;\left(\partial s_{w} / \partial T r^{G}\right)<0$

Public budget/financial side block:

(15) $B=G+\operatorname{Tr}^{G}+b_{u} U+i_{d} D-t_{w}\left[w N+\operatorname{Tr}^{G}+b_{u} U\right]-t_{\pi}\left[\Pi-i_{c r} C R\right]-$ $t_{\pi}\left[i_{c r} C R+i_{d} D\right]$ or:

(15.b) $\frac{B}{K}=\xi=\gamma+\left(1-t_{w}\right)\left[b_{u} \frac{\beta}{\alpha}(1-\chi)+\rho\right]+\left(1-t_{\pi}\right) i_{d} \Delta-t_{w} w \frac{\beta}{\alpha}-t_{\pi} r$

(16) $i_{c r}=(1+\mu) i_{d}$

(17) $i_{d}=\phi\left(\frac{B}{Y}, \Omega\right)$ with $\left(\partial \phi / \partial\left(\frac{B}{Y}\right)\right)>0$ if $\Omega=0 ;\left(\partial \phi / \partial\left(\frac{B}{Y}\right)\right)=0$ if $\Omega=I$ 
Equation (1) tells us that production $(Y)$ is carried out through a fixed-coefficient technology, with $N$ as the employed labor force and $\alpha$ as the average labor productivity. Equation (2) defines potential output $\left(Y^{*}\right)$ as the production level that would be realized in the event that total labor force $(L)$ is fully employed. Equation (3) gives us the out$\mathrm{put} / \mathrm{capital}$ ratio as the product between capacity utilization $\chi\left(=Y / Y^{*}\right)$, which is a measure of the output gap, and $\beta\left(=Y^{*} / K\right)$, that is the highest degree of capital utilization when production is at full potential ${ }^{11}$. According to equations (1) and (2), equations (4) and (4.b) define total unemployment $U$ and the unemployment rate $u$, respectively. Equations (5), (6) and (7) define the nominal wage rate $w$, the domestic price level $p_{H}$, and the real exchange rate $q$. In equation (6), domestic firms set the domestic price level $p_{H}$ by applying a mark-up $m$ on variable unit costs $w / \alpha$. In equation (5), nominal wages are established through a bargaining process between trade unions and firms. More in details, we assume nominal wages $w$ to be positively related to the expected price level $p^{e}$ and the degree of labor market protection $z$, which is in turn a positive function of unemployment benefits $b_{u}$. We also assume the current nominal wage rate to be negatively influenced by previous period unemployment $u_{-1}$, since that it would reduce trade unions' bargaining strength in the current round of wage negotiations. Equation (8) simply states that the value of production is distributed among the total wage bill $W$ and aggregate profits $\Pi$.

In the demand-side block, equation (9) simply gives us the equilibrium condition on the good market and makes explicit all the components of the aggregate demand, i.e. domestic consumption $C$, domestic investments $I$, public purchases $G$, and net exports $N X$. Equation (10) describes aggregate consumption as a function of wage earners' and profit earners' saving propensities, $s_{w}$ and $s_{\pi}$ respectively. Total consumption obviously also depends on disposable income. In the case of wage earners, this is defined as the sum among the total wage bill $W$ $(=w N)$, public transfers $T r^{G}$ and unemployment benefits $b_{u} U$ provided by the domestic social security system. The domestic government levies a tax rate $t_{w}$ on this kind of income. Profit earners' income is given by

11 In our model we assume that there is plenty of capital stock, and that possibly bottlenecks on the supply side of the economy come from shortages of labor rather than capital. 
the difference between total profits $\Pi$ minus interest payments on the total amount of (past and present) loans received from banks, i.e. $i_{c r} C R$. The tax rate levied on net profits is $t_{\pi}$. In this model, the domestic bank system gets interests on the outstanding amount of private loans $(C R)$ and public debt ( $D$, see below). We assume that it does not pay any interest rate on deposits possibly held by households. For the sake of simplicity, we also assume that banks save all their realized profits (i.e. the difference between positive and negative interests), so that banks' profits do not play any role in determining aggregate consumption.

For the sake of simplicity, equation (10.B) scales down aggregate consumption for the capital stock $K$. Accordingly, $\rho$ and $\lambda$ stand for normalized values of public transfers and private debt, respectively.

Equation (11) defines the current growth rate of the capital stock. In particular, we assume $(I / K)$ as a positive linear function of capacity utilization $\chi$ and of the profit share $r$ (with $a$ and $v$ as the corresponding parameters $)^{12}$. Domestic investments are also negatively affected by by the interest rate on banks' loans $i_{c r}$ through parameter $h$. Keynesian-type animal spirits, finally, are captured by parameter $\sigma$.

Equation (12) gives us public purchases, once again normalized for the existing capital stock $K$, as an exogenous policy variable $\gamma$.

In equation (13), normalized net exports are a linear positive function of the real exchange rate $q$, whilst they depend negatively on domestic capacity utilization $\chi$.

Finally, equation (14) introduces a crucial assumption that directly hinges upon the expansionary austerity literature. In fact, equation (14) assumes that, in an intertemporal time framework and according to, say, a permanent income argument, households' saving propensity may depend positively on the expected future tax rate $t_{w}{ }^{e}$. Current cuts in public expenditures, if sufficiently strong and reliable, may induce households to increase current consumption since that they may expect a lower tax burden tomorrow. By the same token, we also assume households' saving propensity to depend negatively on public transfers. Indeed, it is reasonable to believe that a permanent cut in public transfers, perhaps due to the policy decision of downsizing the provisions of the domestic welfare system (read a less generous domestic pension sys-

12 In this sense, our formalization of the investment function takes inspiration from Bhaduri and Marglin (1990). 
tem), may also induce households to adopt a precautionary stance and save more today in anticipation of lower public transfers tomorrow ${ }^{13}$.

In the financial block, equation (15) gives public balance deficit as the simple difference between government outlays, i.e. government purchases, public transfers, the total amount of unemployment benefits and, finally, interest payments on public debt $i_{d} D$, and government revenues from taxes on households' and firms' income. Equation (15.B) normalizes the public balance deficit for the capital stock $K$, with $\Delta=D / K$.

Equations (16) and (17), finally, try to formalize in the simplest way possible some financial aspects of the economy. In particular, equation (16) says that banks establish interest rate $i_{c r}$ on private loans by applying a mark-up rate $\mu$ on the interest on public bonds. In equation (17), in turn, the interest rate $i_{d}$ on public debt depends on several factors. First, it is a positive function of the current public budget deficit over GDP $B / Y=b=\xi / \beta \chi^{14}$. The higher is public budget deficit, or the lower is public budget surplus, the higher will be the interest rates national governments will have to pay on issued public bonds. Second, and perhaps more relevantly, the dynamics of the interest rate on public debt fundamentally relies upon the degree of monetary sovereignty characterizing the economy. In our model, we capture this point through the institutional variable $\Omega$ in equation (17). More in details, we think $\Omega$ as a bivariate variable taking value 1 in the case of a monetarily sovereign country like the US, or 0 in the case of, say, a Eurozone Member State that issues bonds denominated in a supranational "foreign" currency. In a monetarily sovereign country, public bonds are usually taken as risk-free assets, since that they are denominated in the currency issued by the domestic central bank, and because the domestic central bank will likely intervene any time it likes in order to prevent default risks to emerge. Accordingly, we assume $i_{d}$ to be insensitive to the evolution of the public deficit (surplus) over GDP. Interestingly, this assumption seems to be underpinned by some recent empirical evidence showing that government bonds' yields do not

13 The same logic may apply in presence of a reduction of public benefits to unemployed people that perhaps makes average expected income lower.

14 In this model, we assume the interest rate $i_{d}$ to be a (positive) function of public budget deficit (over GDP) only, and not of the overall public debt-to-GDP ratio. This is, of course, a simplifying assumption. Yet, whilst it makes mathematical passages more tractable, it does not change the meaning or the results of our analysis. 
respond to economic fundamentals such as the solidity of public finances, the growth rate of the economy and surpluses in the current account of the Balance of Payments in the context of "stand-alone" (read monetarily sovereign) countries (see De Grauwe and Ji, 2012) ${ }^{15}$. The institutional setting of the Eurozone is rather different. In fact, Eurozone rules impose national governments to find resources on private financial markets only, and forbid the ECB from buying public bonds (at least on the primary market) and directly financing national governments. The solidity of Eurozone national finances is in the hands of financial operators' will and sentiments. Therefore, the abovementioned positive link between $i_{d}$ and $b$ will hold true.

\subsection{The short-run macroeconomic effects of public transfers' cuts}

In our simple model, we can find out an explicit expression for the level of capacity utilization $\chi$ that ensures the equilibrium on the goods market. Analytically, by plugging equations (10.B) - (13) into (9) and, then, into (3), and by taking into account equations (16) (17), we get:

(18) $\chi=\frac{\left(1-s_{w}\right)\left(1-t_{w}\right)\left(b_{u} \frac{\beta}{\alpha}+\rho\right)+\left[\left(1-s_{\pi}\right)\left(1-t_{\pi}\right)+v\right] r+\sigma+\gamma+\epsilon_{q} q-\left[\left(1-s_{\pi}\right)\left(1-t_{\pi}\right) \lambda+h\right](1+\mu) \phi(.)}{\left[\beta-\left(1-s_{w}\right)\left(1-t_{w}\right) \frac{\beta}{\alpha}\left(w-b_{u}\right)+\epsilon_{\chi}\right]}$

In a very Keynesian fashion, equation (18) simply states that cur rent capacity utilization is a positive function of all demand injections, whilst it depends negatively on those factors that reduce investments.

Let now assume that, according to the expansionary austerity literature, the government implements a restrictive fiscal adjustment such that the cyclically adjusted primary deficit over GDP decreases by an amount equal to $-\theta$. Moreover, in line with the advices of the supporters of expansionary austerity, assume that fiscal consolidation mainly takes the form of a cut in public transfers $\left(i . e . d T r^{G}<0\right)$. In terms of our

15 De Grauwe and Ji (2012), in their analysis of the determinants of government bonds' spreads in both Eurozone countries and "stand-alone" economies, explicitly state that " [in the case of "stand-alone" economies] financial markets do not seem to be concerned with the size of the government debt and of the fiscal space and their impacts on the spreads of stand-alone countries, despite the fact that the variation of these ratios is of a similar order of magnitude as the one observed in the Eurozone (De Grauwe and Ji, 2012, p. 11)”. 
model, if we define the cyclically adjusted primary deficit (over GDP) as $b^{*}, b^{*}=\frac{1}{\beta}\left[\gamma+\left(1-t_{w}\right) \rho-t_{w} w-t_{\pi}\left(r+i_{d} \Delta\right)\right]$ we get:

(19) $d b^{*}=-\theta=\frac{\left(1-t_{w}\right)}{\beta} d \rho=\frac{\left(1-t_{w}\right)}{\beta K} d \operatorname{Tr}^{G}$, so that: $d \operatorname{Tr}^{G}=-\frac{\beta K}{\left(1-t_{w}\right)} \theta$

with $\theta>0$.

In our model, such a fiscal adjustment has a direct and simultaneous short-run effect on both current capacity utilization $\chi$ and overall public balance over GDP $b$. In fact, totally differentiating $\chi$ and $b$, and taking into account the sign of equation (19), we get a system of 2 simultaneous equations for $d \chi$ and $d b$ :

$$
\left\{\begin{array}{c}
d \chi=\frac{-\left[f_{t_{W}^{e}}^{e}\left(1-t_{w}\right)\left(b_{u} \frac{\beta}{\alpha}+\rho\right) d t_{W}^{e}-f_{T r} G\left(b_{u} \frac{\beta}{\alpha}+\rho\right) \beta K \theta\right]-\left(1-s_{W}\right) \beta K \theta-\left[\left(1-s_{W}\right)\left(1-t_{W}\right) \lambda+h\right](1+\mu) \phi_{b} d b}{\left[\beta-\left(1-s_{W}\right)\left(1-t_{w}\right) \frac{\beta}{\alpha}\left(w-b_{u}\right)+\epsilon_{\chi}\right]} \\
d b=-\frac{K}{\chi} \theta-\left[\frac{\left(1-t_{w}\right)\left(b_{u} / \alpha\right)}{\chi}+\frac{b}{\chi}\right] d \chi
\end{array}\right.
$$

with $f_{t_{w}^{e}}>0 ; f_{T r^{G}}<0 ;\left(\phi_{b} \mid \Omega\right) \geq 0 ; d t_{w}^{e}<0$

Equations (20) and (21) below give us the solutions $d \chi^{s}$ and $d b^{s}$ of the system (S.1) reported above. What emerges is that there is not any clear outcome of the restrictive fiscal policy we have assumed. In particular, the sign of equation (20) may be either positive, confirming the expansionary austerity hypothesis, either negative, in line with the traditional Keynesian concern about the recessive effects of fiscal retrenchments. The same applies to equation (21). Public transfers' cuts might help reducing public deficit over GDP or, alternatively, may be counterproductive and lead to an even higher deficit-to-GDP ratio in the event they trigger a contraction of current economic activity. At least theoretically, mixed results may also emerge, according to which fiscal adjustments contribute to reduce fiscal deficits even though they induce a recession ${ }^{16}$.

16 Into such a scenario, $d b^{S}$ would be negative thanks to the direct cut in public transfers even in presence of a negative value of $d \chi^{S}$, i.e. a contraction of short-run economic activity that tends to increase government outlays and government deficit. 
(20) $d \chi^{S}=\overbrace{\frac{[f_{\left.t_{w}^{e}\left(1-t_{w}\right)\left(b_{u} \frac{\beta}{\alpha}+\rho\right)\right]\left|d t_{w}^{e}\right|}-\overbrace{\left[\left(1-s_{w}\right)-f_{T r} G\left(b_{u} \frac{\beta}{\alpha}+\rho\right)\right] \beta K \theta}+\overbrace{\left[\left(1-s_{w}\right)\left(1-t_{w}\right) \lambda+h\right](1+\mu) \frac{K}{\chi} \phi_{b} \theta}^{+ \text {or } 0}}{\left\{\left[\beta-\left(1-s_{w}\right)\left(1-t_{w}\right) \frac{\beta}{\alpha}\left(w-b_{u}\right)+\epsilon_{\chi}\right]-\left[\left(1-s_{w}\right)\left(1-t_{w}\right) \lambda+h\right](1+\mu) \phi_{b}\left[\frac{\left(1-t_{w}\right)(b u / \alpha)}{\chi}+\frac{b}{\chi}\right]\right\}}}^{-}$

(21) $d b^{S}=-\frac{K \theta}{\chi}-\left[\frac{\left(1-t_{w}\right)\left(b_{u} / \alpha\right)}{\chi}+\frac{b}{\chi}\right] d \chi^{S}$

Despite of such a high degree of indeterminacy, a few points are worth stressing.

1. The expansionary outcome of fiscal adjustment heavily depends on the intensity of partial derivative $f_{t_{w}^{e}}$, and of $\left|d t_{w}^{e}\right|$, i.e. the expected reduction (here reported in absolute value) in the tax burden levied on households. The higher and the quicker is $\left|d t_{w}^{e}\right|$, the more rapidly and robustly private consumptions may respond positively to public budget's cuts. Interestingly, and perhaps paradoxically, it is reasonable to imagine that such positive expectations will hardly materialize in an economy characterized by a high public debt stock, i.e. the economic scenario in which, according to the supports of expansionary austerity, fiscal consolidation is primarily needed. Indeed, when public debt $D$ is considerably high and a prolonged period of fiscal consolidation is foreseen, people will likely expect future tax reductions to be modest and take place much farther ahead (at least with respect to current spending cuts). In such a context, the "expectation channel" through which expansionary austerity may work is extremely weak at best, and likely more than compensated by the overwhelming contractionary effect of current public transfers' cuts.

2. Public transfers' cuts, expansionary austerity proponents say, may also boost growth by reducing public deficit, hence interest rate $i_{d}$ on public bonds and, above all, interest rate $i_{c r}$ on banks' loans to the private sector. Such a reduction in the cost of external financing may in fact spur private investment and induce the economy to expand. According to our model, however, such an effect of fiscal adjustments on interest rates does not take place in monetarily sovereign economies. Indeed, following equations (16) and (17), in the case of monetarily sovereign countries, the "financial market channel" through which fiscal consolidation may affect economic dynamics simply disappears. Accordingly, in equation (20), the allegedly expansionary impact of fiscal consolidation turns out to be even weaker at the very best. In the end, in the case of "stand-alone" countries, faith 
in fiscal adjustments as useful policy options to reduce government bonds' interest rates and, by this way, make banks' credit more accessible to private actors, is misplaced and ungrounded at the very least. The "financial market channel" might be at work in the case of Eurozone countries that issue public bonds denominated in a supranational currency, and in which the solidity of public finances and of the overall financial system hinge upon financial markets' sentiments. In such a context, one could be persuaded that front-loaded fiscal adjustments might reassure financial markets about the sustainability of Eurozone countries' fiscal positions and that, eventually, they might more easily entail expansionary effects. Of course, this logic may hold true if designed fiscal adjustments effectively lower public deficits and debt-to-GDP ratios. Yet, we are very far from taking such a possible effect of fiscal consolidation as guaranteed. Indeed, recent empirical evidence shows that it is hard to find a way out from public balance disarrays without sustained growth (Ali Abbas et al., 2013 $)^{17}$, and that fiscal multipliers may be high and positive when economies are in the midst of a recession or are operating below potential (Batini et al., 2012; Baum et al., 2012). If so, too severe and premature fiscal retrenchments may actually induce a short-run deterioration in fiscal and financial variables, instead of improving them, by jeopardizing growth performances ${ }^{18}$.

In terms of our model, such an undesirable outcome of public transfers' cuts emerges clearly from the above two expressions for $d \chi$ and $d b$. Let assume, for instance, that at the beginning of a fiscal austerity program the "expectation channel" is weak, and/or interest rates do

17 Ali Abbas et al. (2013) analyze 26 episodes of large debt reversals in advanced economies. They find out that "periods of decreasing debt were often associated with higher growth rates and strong primary balances [...] Historically, debt reductions have tended to be smaller and less frequent in more challenging macroeconomic environments of moderate growth (Ali Abbas et al., 2013, p. 3)".

18 Ali Abbas et al. (2013) also note that "front-loaded consolidations have tended to increase public debt in the short run [...] Empirically, fiscal effort has been more likely to reduce public debt when growth has been stronger [whilst] the debt-toGDP ratio increases in the short run when fiscal consolidations come at the cost of lower economic activity. [In the end] while credibility effects can ease the pain of fiscal adjustment through lower risk premiums, this is unlikely to fully offset the short-run adverse impact on economic activity (Ali Abbas et al., 2013, p. 3)”. 
not respond promptly or enough intensively to the announcement of public budget cuts. In such a context, fiscal austerity likely reduces the economic activity and makes $d \chi$ negative. Economic slowdown (or recession), in turn, tends to frustrate initial government's efforts to squeeze budget deficits or run fiscal surpluses due to the negative impact it carries out on public budget via automatic stabilizers. Very likely, the public debt-to-GDP ratio, if not the deficit-to-GDP ratio, will increase rather than decrease. In our model, a rise in the deficitto-GDP ratio will put further strain on financial markets and induces a second round contraction of economic activity. Eventually, the results of fiscal cuts could be opposite than those expected by the supporters of expansionary austerity even when the "financial market" or "credibility" channel is judged to be relevant to stabilize macroeconomic real and financial variables.

3. Last but not least, since 2012, the monetary scenario prevailing in the Eurozone resembles more closely that one characterizing the US since the outbreak of the worldwide financial crisis and "Great Recession". Indeed, thanks to Mario Draghi's pledge that he will do "whatever it takes" to save the Euro, and after the launch of the Outright Monetary Transaction (OMT) program, financial speculation on peripheral countries' government bonds has calmed down. Interest rates $i_{d}$ have decreased significantly. They are currently at historically minimum levels, and may be expected to decrease even further in the event the ECB would adopt additional expansionary monetary measures to avoid deflation and try to rescue the Eurozone from secular stagnation. In such a context, it makes sense to wonder the effectiveness of the "financial channel" through which fiscal austerity is expected to positively contribute to economic recovery. As Roberto Perotti himself stresses, "if fiscal consolidations were expansionary in the past because they caused a steep decline in interest rates or inflation, it is unlikely that the same mechanism can be relied on in the present circumstances, with low inflation and interest rates close to zero (Perotti, 2012, p. 309)".

\subsection{The short-run macroeconomic effects of lower unemployment benefits}

An additional proposition of the expansionary austerity doctrine is that fiscal adjustments should also aim at reforming the labor market, directly or indirectly. Cuts in public wages or public employment, for 
instance, may induce wage rate moderation, this way improving the external competitiveness of the economy. An increasing external demand for domestic goods may in turn foster economic activity and growth. The same logic applies to reductions in the provision of the welfare system, which takes the form of lower unemployment benefits $b_{u}$. In fact, a reduction in the "reserve" income workers would get in the event of unemployment would force trade unions to bargain lower nominal wages $w$.

In our model, the short-run effects of these additional fiscal austerity measures are formalized in system (S.2):

$(\mathrm{S} .2)\left\{\begin{array}{c}d \chi=\frac{-}{\frac{+}{\left(1-s_{w}\right)\left(1-t_{w}\right)(\beta / \alpha)\left[(1-\chi)+\left(\partial w / \partial b_{u}\right) \chi\right] d b_{u}}+\frac{+}{\left[\beta-\left(1-s_{w}\right)\left(1-t_{w}\right) \frac{\beta}{\alpha}\left(2 q-b_{u}\right)+\epsilon_{\chi}\right]}} \\ d b=\frac{\left(1-t_{w}\right)(1-\chi)}{\alpha \chi} d b_{u}-\left[\frac{\left(1-t_{w}\right)\left(b_{u} / \alpha\right)}{\chi}+\frac{b}{\chi}\right] d \chi\end{array}\right.$

with $\left(\partial w / \partial b_{u}\right)>0 ;(\partial q / \partial w)<0 ; d b_{u}<0$.

Equations (22) and (23) give the solutions of system (S.2):

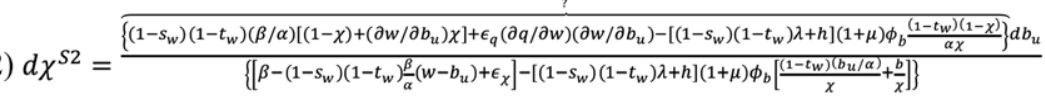

$d b^{S 2}=\frac{\left(1-t_{w}\right)(1-\chi)}{\alpha \chi} d b_{u}-\left[\frac{\left(1-t_{w}\right)\left(b_{u} / \alpha\right)}{\chi}+\frac{b}{\chi}\right] d \chi^{S 2}$

Once again, it stands out clearly than no clear-cut solutions exist, and that the theoretical basis of the expansionary austerity doctrine is extremely weak. In particular, when the direct and indirect effects (i.e. the decrease in monetary wages $w$ ) of cuts in unemployment benefits are taken into account, the immediate outcome of such measures is lower demand injections in the form of lower consumption expenditures. Of course, the contraction in the domestic component of aggregate demand might well be compensated by an increasing external demand for homemade goods that might emerge in presence of lower domestic nominal wages $w$ and, thus, of a depreciated real exchange rate $q$. However, increasing net exports and, possibly, booming economic activity, strongly rely upon the sensitiveness of net exports to the real exchange rate, which in turn is conditional to the sectorial composition of net exports themselves and to the degree of openness of the economy (see Taylor, 1991, 
ch.7). In this regards, it is perhaps not by chance that one of the most cited examples of successful expansionary austerity is that one taking place in Ireland in late 1980s. Indeed, Ireland is now a small open economy that is highly integrated on international goods markets, and that exports a restricted but highly dynamic variety of manufactured products (see pharmaceutical products, for instance). And at the end of the 1980s Irish exports were already accounting for more than 50 percent of Irish GDP. Interestingly, Perotti (2012) himself recognizes that a fundamental pillar of late 1980s Irish economic rebound was the solid expansion of Irish exports due to domestic wage moderation and fast reduction in inflation plus the initial one-shot devaluation of the Irish pound, the stabilization of the British sterling, and the economic expansion of Britain, i.e. Ireland's most important trade partner. Now, it is worth noting that, first, part of the above policy recipe, i.e. the devaluation of the domestic currency, is not available in Eurozone countries any longer. Second, it is questionable that a small peripheral Eurozone country like Greece could currently follow and adopt that same development pattern. Indeed, Greece is a small, relatively closed ${ }^{19}$ and largely de-industrialized ${ }^{20}$ economy. Accordingly, there are reasonable doubts that the emphasis on internal devaluation as sponsored by the supporters of the expansionary austerity would actually give the same results in Greece as wage moderation supposedly did in Ireland when combined with other no-more available policy options, and when applied in a much more favorable worldwide economic scenario.

As to the operativeness of the "financial channel", the same line of reasoning developed in section 3.1 applies also to the case of cuts in unemployment benefits. It might have some relevance, but only in the case of non-fully monetarily sovereign economies, and according to the capability of fiscal adjustments of effectively squeezing public balance deficit over GDP without throwing the economy in a deep recession.

19 According to trade data provided by UNCTAD, in 2013, Greek exports in good and services account for less than 28 percent of Greek GDP.

20 In 2013, Greece's exports of manufactured goods account for the 30 percent of total Greece merchandise exports only. Even further, in 2013, the manufacturing GDP share is equal to less than 9 percent (it was barely higher than 15 percent in 1987). In the case of Ireland, since 1987 on, the manufacturing GDP share has never decreased below 19 percent, even in periods of bad worldwide recession and decreasing international trade flows. 


\section{CONCLUSiOnS}

In this paper, we provide a critical analysis of the expansionary austerity theory. We first review the critiques moved to the expansionary austerity doctrine from an empirical point of view. According to these critiques, the econometric techniques on which the expansionary austerity literature largely relies upon are fundamentally flawed because they are biased towards estimating lower (than effective) or even negative fiscal multipliers. We then present a very simple short-run model in order to address the theoretical weaknesses of the expansionary austerity theory. In particular, we show that the expansionary outcomes of well-designed fiscal adjustments might materialize only in specific economic environments and under peculiar circumstances. For sure, they cannot be taken for granted and they do not represent the results of a well-established universal law.

First, we show that the downsizing of the welfare state might boost private consumption only under the unrealistic condition that expected and uncertain future reductions in the tax burden will more than compensate for the current, permanent and certain cut in public transfers.

Second, the "financial channel" through which fiscal corrections may crowd in private investments does not seem to work in the case of monetarily sovereign economies. It could perhaps work in the case of Eurozone countries, but only if fiscal consolidation does effectively trigger off a reduction in the public deficit-to-GDP ratio, and thus help to create a safer financial environment. However, such a virtuous effect of fiscal consolidation on public balance's solidity is all but certain in the short run. Quite the opposite, recent empirical evidence tends to suggest that front-loaded fiscal adjustments actually increase the debtto-GDP ratio, if not the public deficit, due to their recessive impacts on economic activity.

Last but not least, austerity measures aiming at restoring external competitiveness through internal devaluation (read wage moderation) might be expansionary only in the case of economic systems that are deeply integrated on international goods markets, and that exports highly dynamic products. Historically, this was the economic setting characterizing a few episodes of expansionary fiscal adjustments that were implemented together with some additional policy measures, the devaluation of the domestic currency first and foremost. However, a small peripheral Eurozone country like Greece does not currently show 
any of those features characterizing Ireland at the end of the 1980s. Moreover, the toolkit of Eurozone policymakers is now much narrower than it was thirty years ago. Accordingly, there are very good reasons to question the validity of the expansionary austerity mantra.

\section{REFERENCES}

A. Alesina, and S. Ardagna, The Design of Fiscal Adjustments, NBER Working Paper n. 18423, 2012.

A. Alesina, and S. Ardagna, Large Changes in Fiscal Policy: Tax versus Spending, in J.R. Brown (ed.), Tax Policy and the Economy, 2010, 35-68.

A. Alesina, and R. Perotti, Fiscal Expansions and Fiscal Adjustments in OECD Countries, NBER Working Paper n. 5214, 1995.

S. Ali Abbas, B. Akitoby, J. Andritzki, H. Berger, T. Komatsuzaki, and J. Taylor, Dealing with High Debt in a Era of Low Growth, IMF Staff Discussion Note 13/07, 2013.

N. Batini, G. Callegari, and G. Melina, Successful Austerity in the United States, Europe, and Japan, IMF Working Paper n. 190, 2012.

A. Baum, M. Poplawski-Ribeiro, and A. Weber, Fiscal Multipliers and the State of the Economy, IMF Working Paper n. 286, 2012.

A. Bhaduri, and S. Marglin, Unemployment and the Real Wage: The Economic Basis for Contesting Political Ideology, Cambridge Journal of Economics, 14 (4), 375 - 393.

P. De Grauwe, and Y. Ji, Self-fulfilling Crises in the Eurozone: An Empirical Test, CEPS Working Document n. 367, 2012.

F. Giavazzi, and M. Pagano, Can Severe Fiscal Contractions Be Expansionary? Tales of two Small European Countries, NBER Macroeconomic Annual, 5, 1990, 75-122.

F. Giavazzi, and M. Pagano, Non-Keynesian Effects of Fiscal Policy Changes: International Evidence and the Swedish Experience, Swedish Economic Policy review, 39 (3), 1996, 635-657.

J. Guajardo, D. Leigh, and A. Pescatori, Expansionary Austerity: New Empirical Evidence, IMF Working Paper n. 158, 2011.

T. Herndon, M. Ash, and R. Polin, Does High Public Debt Consistently Stifle Economic Growth? A Critique of Reinhart and Rogoff, PERI Working Paper n. 322, 2013.

T. Palley, The Simple Macroeconomics of Fiscal Austerity, Public Sector Debt and Deflation, IMK Working Paper n. 8/2010, 2010.

R. Perotti, The "Austerity Myth": Gain without Pain?, in A. Alesina, and F. Giavazzi (eds), Fiscal Policy after the Financial Crisis, University of Chicago Press, 2012, 307-354.

C.M. Reinhart, and K.S. Rogoff, Growth in a Time of Debt, American Economic Review Papers and Proceedings, 100 (May), 573-578.

A. Sutherland, Fiscal Crises and Aggregate Demand: Can High Public Debt Reverse the Effect of Fiscal Policy?, Journal of Public Economics, 1997, 147-162.

L. Taylor, Income Distribution, Inflation and Growth: Lectures on Structuralist Macroeconomic Theory, MIT Press: Cambridge (USA) and London (UK), 1991, ch. 7,143-150. 